\title{
PENINGKATAN HASIL BELAJAR SISWA MELALUI MODEL PEMBELAJARAN GROUP INVESTIGATION PADA MATERI METABOLISME KELAS XII MIPA 1 SMA NEGERI 1 MAKASSAR
}

\author{
Ernawati Nur \\ SMA Negeri 1 Makassar, ernawatismansa@gmail.com
}

\begin{abstract}
Abstrak
Penelitian tindakan kelas ini bertujuan untuk meningkatkan hasil belajar siswa melalui penerapan model pembelajaran Group Investigation. Subjek penelitian ini adalah 36 siswa kelas XII MIPA 5 tahu pelajaran 2019/2020. Penelitian ini terdiri dari dua siklus, data hasil belajar siswa diperoleh melalui tes di setiap akhir siklus. Hasil peneltian yang berupa hasil belajar siswa dianalisis secara analisis deskriptif. Hasil penelitian menunjukkan bahwa penerapan model pembelajaran Group Investigation dapat meningkatkan hasil belajar siswa kelas XII MIPA 5. Peningkatan tersebut ditunjukkan oleh data penelitian yaitu rata-rata nilai hasil belajar siswa meningkat dari 62,06 pada siklus I menjadi 86,94 pada siklus II. Berdasarkan hal tersebut dapat disimpulkan bahwa melalui penerapan model pembelajaran Group Investigation dapat meningkatkan hasil belajar siswa kelas XII MIPA 5 pada materi metabolism.
\end{abstract}

Kata kunci: Group Investigation, hasil belajar siswa

\begin{abstract}
This classroom action research aims to improve student learning outcomes through the application of the Group Investigation learning model. The subjects of this study were 36 students of class XII MIPA 5 in the 2019/2020 lesson. This study consisted of two cycles, data on student learning outcomes were obtained through tests at the end of each cycle. The results of the research in the form of student learning outcomes were analyzed using descriptive analysis. The results showed that the application of the Group Investigation learning model can improve the learning outcomes of students in class XII MIPA 5. This increase is shown by research data, namely the average value of student learning outcomes increased from 62.06 in cycle I to 86.94 in cycle II. Based on this, it can be concluded that through the application of the Group Investigation learning model it can improve student learning outcomes in class XII MIPA 5 on metabolism material.
\end{abstract}

Keywords: Group Investigation, learning outcomes 


\section{PENDAHULUAN}

Kemajuan peradaban manusia tidaklah lepas dari kemajuan ilmu pengetahuan dan teknologi (IPTEK). Semua Negara berpacu dan bersaing di dalam dunia IPTEK, membuat produkproduk dan karya yang begitu canggih. Kecanggihan IPTEK pun sudah memasuki berbagai bidang mulai dari energi, kesehatan, hingga pendidikan. Melihat kemajuan dan kecanggihan IPTEK tentunya tidak lepas dari kontribusi generasi muda. Generasi muda yang berkompeten merupakan salah satu faktor penentu kemajuan IPTEK suatu Negara.

Generasi muda merupakan investasi besar bagi masa depan suatu bangsa dan Negara. Generasi muda yang berkompeten dapat dibentuk melalui pendidikan yang berkualitas. Melalui pendidikan, generasi muda diberikan bekal dan dibentuk karakternya sehingga menghasilkan sumber daya manusia yang berkompeten di bidangnya.

Pendidikan saat ini tidak lagi berfokus pada keterampilan siswa untuk menghapal materi pelajaran semata. Pendidikan saat ini mengarahkan siswa bagaimana memecahkan masalah dan menacari solusi dari masalah tersebut.
Kegiatan tersebut akan merangsang pemikiran siswa lebih jauh dari sekedar menghapal semata.

Berdasarkan hasil observasi di kelas, kemampuan siswa untuk memecahkan masalah masih tergolong rendah. Saat diberikan soal ujian dengan tingkat kognitif yang lebih tinggi dan memerlukan nalar yang lebih tinggi masih banyak siswa yang kesulitan dalam menjawab. Tentunya hal tersebut berimbas pada nilai hasil belajar mereka. Sebagian besar siswa hanya menghapal materi pelajaran saja dan kurang memahaminya. Mereka terbiasa dengan soal ujian dengan tipe jawaban hanya memindahkan informasi dari buku teks mereka.

Salah satu solusi untuk merangsang daya pikir siswa dari hanya sekedar menghapal adalah merancang pembelajaran yang lebih menantang. Siswa diajak untuk menyelesaikan masalah yang berkaitan dengan materi pelajaran. Bedasarkan hal tersebut maka, perlu adanya penerapan model pembelajaran yang dapat menciptakan suasana belajar seperti itu. Salah satu model pembelajaran yang dapat diterapkan adalah model pembelajaran Group Investigation. 
Jurnal Binomial Vol. 3 No. 2 September 2020

Model pembelajaran Group Investigation merupakan salah satu tipe model pembelajaran kooperatif. Pada proses pembelajaran yang menggunakan Group Investigation siswa dikelompokkan dalam kelompok kecil, siswa bekerja dengan melibatkan inquiri kooperatif, berdisikusi dengan dengan teman kelompoknya dan pada akhir pembelajaran siswa mempresentasikan apa yang mereka temukan di depan kelas Pramukantoro, (2013).

Melalui penerapan model pembelajaran Group Investigation diharapkan siswa mampu lebih aktif dalam memecahkan masalah sehingga pengetahuan yang mereka dapat lebih luas dari sekedar menghapal teks di dalam buku mereka. Tentunya ini akan berdampak pada meningkatnya hasil belajar mereka. Seperti penelitian yang dilakukan oleh Sari (2016) bahwa melalui penerapan model pembelajaran Group Investigation dapat meningkatkan hasil belajar siswa sebesar $28,16 \%$. Tidak hanya itu hasil belajar afektif juga mengalami peningkatan 29,02\% dan hasil belajar psikomotor sebesar $10,42 \%$.

Selain hasil belajar model pembelajaran Group Investigation juga mampu merangsang kemampuan berpikir kritis siswa. Penelitian yang dilakukan oleh Wijayanti (2013) bahwa model pembelajaran Group Investigation ini memungkinkan siswa untuk berpartisipasi aktif dalam mencari sendiri materi pelajaran dari berbagai sumber informasi yang relevan seperti buku pelajaran, dan berbagai laman dari internet. Melalui kegiatan membaca berbagai referensi maka secara langsung menambah pengetahuan siswa yang tentunya dapat mendorong daya berpikir kritis.

Berdasarkan uraian di atas maka peneliti melaksanakan penelitian dengan judul Peningkatan Hasil Belajar Siswa Melalui Model Pembelajaran Group Investigation pada Materi Metabolisme Kelas XII MIPA 1 SMA Negeri 1 Makassar

\section{METODE PENELITIAN}

Penelitian ini merupakan penelitian tindakan kelas yang terdiri dari beberapa siklus. Setiap siklus terdiri dari 4 tahapan yaitu; 1) Perencanaan, 2) Pelaksanaan tindakan, 3) Observasi dan Evaluasi, 4) Refleksi.

Siklus penelitian ini dapat dilihat pada gambar di bawah ini 
Jurnal Binomial Vol. 3 No. 2 September 2020

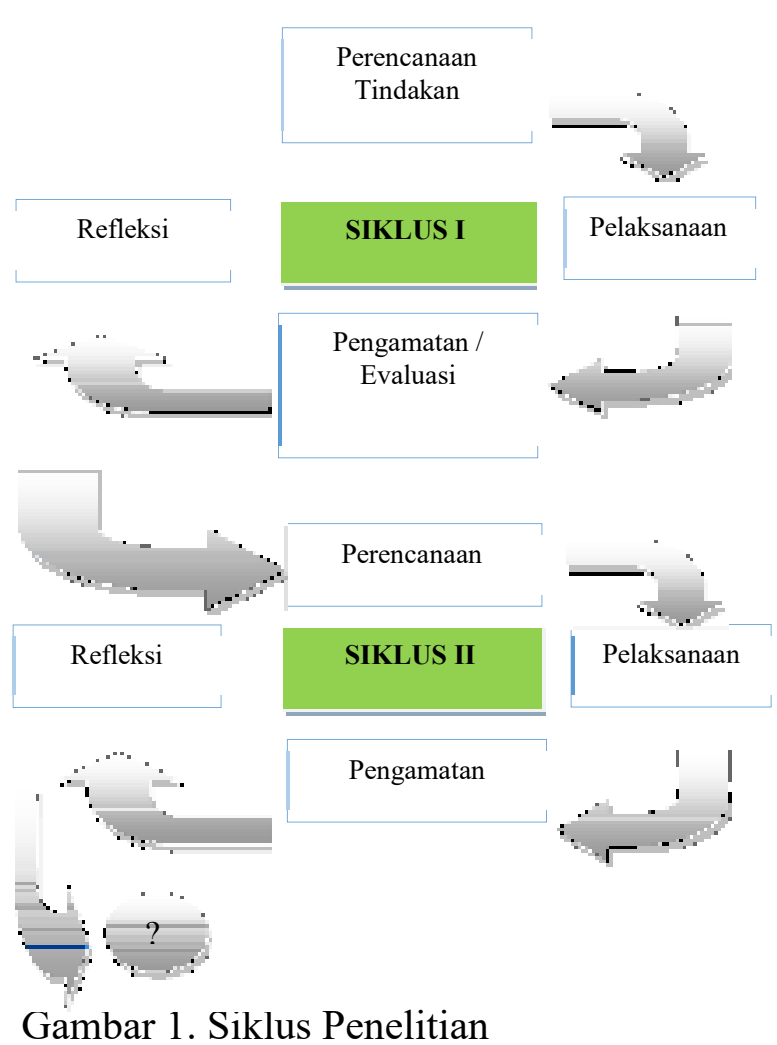

Subjek penelitian adalah siswa kelas XII MIPA5 SMA Negeri 1 Makassar tahun ajaran 2019-2020 yang berjumlah 36 orang.

Faktor yang akan diselidiki pada penelitian ini adalah hasil belajar siswa pada materi metabolime setelah diajar dengan menggunakan model pembelajaran Group Investigation.

Instrumen yang digunakan dalam penelitian ini ini adalah tes hasil belajar yang berupa pilihan ganda berjumlah 30 nomor. Teknik pengumpulan data hasil belajar siswa diperoleh melalui tes hasil belajar di setiap akhir siklus. Teknik analisis data yang digunakan untuk mengolah data dengan statistik deskriptif.

Tabel 1. Kriteria Hasil Belajar Siswa

\begin{tabular}{|c|c|}
\hline Interval Nilai & Kategori \\
\hline $93-100$ & Sangat Baik \\
\hline $84-92$ & Baik \\
\hline $75-83$ & Cukup \\
\hline $0-74$ & Kurang \\
\hline \multicolumn{2}{|c|}{ Jumlah } \\
\hline \multicolumn{2}{|c|}{ Indikator }
\end{tabular}

penelitian ini adalah jika nilai rata-rata hasil belajar siswa pada materi metabolime mencapai 75

Tabel 2. Kriteri Ketuntasan Minimal SMA Negeri 1 Makassar

\begin{tabular}{|c|l|}
\hline $\begin{array}{c}\text { Nilai Hasil } \\
\text { Belajar }\end{array}$ & \multicolumn{1}{|c|}{ Kategori } \\
\hline$\geq 77$ & Tuntas \\
\hline$<77$ & Tidak Tuntas \\
\hline \multicolumn{2}{|c|}{ Jumlah } \\
\hline
\end{tabular}

\section{HASIL DAN PEMBAHASAN}

\section{A. Hasil Penelitian}

Data hasil belajar siswa siklus I dan siklus II diperoleh dari tes pada setiap akhir siklus. Berikut disajikan distribusi frekuensi nilai hasil belajar siswa pada materi metabolisme setelah diajar dengan menggunakan model 
Jurnal Binomial Vol. 3 No. 2 September 2020

pembelajaran Group Investigation pada

siklus I dan siklus II

Tabel 3. Distribusi dan presentase skor hasil belajar Biologi siswa kelas XII IPA 5 SMAN 1

Makassar

\begin{tabular}{|c|c|c|c|c|c|}
\hline \multirow{2}{*}{$\begin{array}{c}\text { Interval } \\
\text { Nilai }\end{array}$} & \multirow{2}{*}{ Kategori } & \multicolumn{2}{|c|}{ Siklus I } & \multicolumn{2}{|c|}{ Siklus II } \\
\hline & & $\mathrm{f}$ & $\%$ & $\mathrm{f}$ & $\%$ \\
\hline $93-100$ & $\begin{array}{c}\text { Sangat } \\
\text { Baik }\end{array}$ & 0 & 0 & 5 & 13.9 \\
\hline 84-92 & Baik & 0 & 0 & 21 & 58.3 \\
\hline $75-83$ & Cukup & 14 & 38.9 & 10 & 27.8 \\
\hline $0-74$ & Kurang & 22 & 61.1 & 0 & 0 \\
\hline \multicolumn{2}{|c|}{ Jumlah } & 36 & 100 & 36 & 100 \\
\hline
\end{tabular}

Berdasarkan tabel di atas, pada siklus I sebagian besar siswa berada pada kategori kurang yaitu dengan persentase $61.1 \%$ dan sebagian siswa berada pada kategori cukup yaitu sebesar 38.9\%. Setelah dilakukan refleksi untuk melihat kekurangan dan kendala yang terjadi selama proses pembelajaran pada siklus I kemudian memperbaikinya.

Maka, didapatkanlah hasil adanya peningkatan hasil belajar siswa pada siklus II yang dapat dilhat pada tabel di atas bahwa sebagian besar nilai siswa berada pada kategori baik yaitu sebesar $58,83 \%$ sementara $13,9 \%$ siswa berada pada kategori sangat baik. Berikut disajikan data siswa yang telah mencapai KKM pada siklus I dan II:
Tabel 4. Ketuntasan Belajar Siswa

\begin{tabular}{|c|l|c|c|c|c|}
\hline \multirow{2}{*}{$\begin{array}{c}\text { Nilai } \\
\text { Hasil } \\
\text { Belajar }\end{array}$} & \multirow{2}{*}{ Kategori } & \multicolumn{2}{|c|}{ Siklus I } & \multicolumn{2}{c|}{ Siklus II } \\
\cline { 3 - 6 } & & $\mathrm{f}$ & $\%$ & $\mathrm{f}$ & $\%$ \\
\hline$\geq 77$ & Tuntas & 14 & 38.9 & 36 & 100 \\
\hline$<77$ & $\begin{array}{l}\text { Tidak } \\
\text { Tuntas }\end{array}$ & 22 & 61.1 & 0 & 0 \\
\hline \multicolumn{2}{|c|}{ Jumlah } & 36 & 100 & 36 & 100 \\
\hline
\end{tabular}

Tabel 4 menunjukkan bahwa pada siklus I sebagian besar siswa belum mencapai KKM yaitu sebesar $61,1 \%$ sedangkan siswa yang telah mencapai KKM hanya $38.9 \%$. Setelah dilakukan tes pada akhir siklus II, diperolehlah data yang menunjukkan bahwa 100\% siswa telah mencapai KKM.



Gambar 2. Persentase Pencapaian KKM

Setelah dilakukan analisis deskriptif nilai rata-rata hasil belajar siswa dari siklus I ke siklus II mengalami peningkatan. Pada siklus I nilai rata-rata hasil belajar siswa adalah 
62,06 sedangkan pada siklus II nilai rata-rata hasil belajar siswa adalah 86,94. Hal ini menunjukkan bahwa model pembelajaran Group Investigation dapat diterapkan pada proses pembelajaran untuk meningkatkan hasil belajar siswa.

\section{B. Pembahasan}

Berdasarkan hasil penelitian bahwa melalui penerapan model pembelajaran Group Investigation terjadi peningkatan hasil belajar siswa yang ditunjukkan dengan meningkatnya nilai rata-rata hasil belajar dan persentase siswa yang telah mencapai nilai KKM yang telah ditetapkan sekolah. Nilai rata-rata hasil belajar siswa pada siklus I adalah 62,06 dan pada siklus II mengalami peningkatan menjadi 86,94. Sedangkan untuk persentase siswa yang telah mencapai KKM pada siklus I sebesar 38,9\% dan meningkat di siklus II hingga mencapai $100 \%$. Hal ini dapat memberikan gambaran bahwa model Group Investigation bagus untuk diterapkan di dalam proses pembelajaran.

Pembelajaran pada siklus I dengan menerapkan model pembelajaran Group Investigation masih ada kendala dan kekurangan yang terjadi selama proses pembelajaran. Masih ada beberapa siswa yang kurang aktif dalam proses pembelajaran. Mereka masih enggan untuk berdiskusi dengan kelompoknya, beberapa siswa hanya duduk mengamati dan menyerahkan kepada temannya untuk mengerjakan tugas yang diberikan dan sesekali bercerita dengan teman kelompoknya. Hal ini terjadi pada tahap investigasi dan pembuatan laporan akhir. Lalu, pada saat presentasi atau menyajikan hasil investigasi mereka di depan kelas, jumlah siswa yang mencapai nilai KKM masih cukup rendah hanya $38,9 \%$. Peneliti melakukan beberapa siswa masih cenderung malu untuk tampil. Saat diberi kesempatan untuk tampil, hanya beberapa siswa yang bersedia dengan mengangkat tangannya.

Hasil refleksi dari siklus I menjadi tolak ukur untuk melakukan perbaikan di siklus II. Peneliti memperbaiki kekurangan yang terjadi di siklus I. Untuk merangsang agar siswa lebih aktif, peneliti lebih memberikan motivasi agar mereka ikut berdiskusi dengan teman kelompoknya. Peneliti memberikan reward bagi kelompok terbaik dalam melakukan investigasi dan penyajian laporan hasil investigasi. 
Peneliti lebih banyak mendampingi siswa saat sedang melakukan diskusi. Kemudian untuk siswa yang masih malu dan canggung selama proses pembelajaran dengan model pembelajaran Group Investigation, peneliti terus memberikan motivasi dan semangat. Sesekali menunjuk siswa secara langsung untuk tampil di depan kelas menyajikan hasil investigasi mereka. Mungkin kekurangankekurangan tersebut terjadi karena siswa belum terbiasa dengan penerapan model Group Investigation ini.

Setelah melakukan perbaikan pada proses pembelajaran di siklus II dengan bercermin dari hasil siklus I, sudah mulai ada perubahan aktifitas siswa selama proses pembelajaran dengan menggunakan model pembelajaran Group Investigation ini. Siswa terlihat lebih aktif saat proses pembelajaran, siswa aktif berdiskusi dengan teman kelompoknya dan melakukan investigasi. Siswa yang masih canggung dan malu sudah mulai percaya diri saat diberikan kesempatan untuk tampil menyajikan hasil investigasi mereka. Hal ini dikarenakan peneliti mencoba menciptakan suasan belajar yang santai tetapi serius, agar siswa tidak merasa tegang. Peneliti mencoba membuat proses pembelajaran dengan model Group Investigation ini lebih menyenangkan dan memberikan reward di akhir pelajaran. Tidak lupa peneliti juga memberikan penghargaan dan penguatan bagi setiap siswa yang aktif dalam proses pembelajaran, agar mereka lebih termotivasi dalam belajar. Selain itu, siswa juga sangat bersemangat saat memasuki laboratorium untuk melakukan paktikum tentang materi metabolisme yang sedang mereka pelajari. Sebagian besar siswa antusias melakukan eksperimen mengenai pengaruh konsentrasi substrat terhadap aktivitas enzim. Berdasarkan hasil perbaikan di siklus II, hasil tes yang dilakukan di akhir siklus II telah mencapai hasil yang baik. Jumlah siswa yang telah lulus KKM encapai $100 \%$. Nilai rata-rata hasil belajar pun mengalami peningkatan.

Melalui pembelajaran yang menggunakan model Group Investigation, siswa menjadi terlibat aktif di dalam proses pembelajaran. Awalnya siswa lebih aktif mendengar namun pada proses pembelajaran selama siklus I dan II siswa terlibat aktif dalam diskusi kelompok dengan teman kelompoknya. Seperti yang 
diungkapkan oleh Darmadi (2017) yang mengutip dari Slavin mengenai tahapan pembelajaran Group Investigation yaitu pada tahap investigasi siswa akan terlibat secara aktif dalam kelompoknya untuk bertukar informasi dan ide, berdiskusi, klarifikasi, mengumpulkan informasi, menganalisis data dan melakukan inferensi.

Pada saat pembelajaran siklus I dan II siswa berdiskusi dengan teman kelompoknya mengenai topik yang disajikan. Siswa aktif mencari berbagai informasi mengenai topik yang diberikan. Tentunya jika siswa mendapatkan informasi mengenai materi pelajaran secara mandiri akan jauh lebih bermakna dan tersimpan di memori jika dibandingkan informasi yang diperoleh hanya dengan mendengarkan saja.

Pada implementasi model pembelajaran Group Investigation (GI), siswa bekerjasama dalam kelompok untuk mencermati suatu topik serta menggali pengetahuan yang terkait dengan topik tersebut dari berbagai sumber, antara lain seperti buku, koran, internet, observasi secara langsung, dan lain sebagainya, sehingga didapatkan pengetahuan-pengetahuan baru yang bersifat lebih luas (Suryanda et al., 2018)

Selain merangsang keaktifan siswa, model pembelajaran Group Investigation juga merangsang kemampuan berpikir kritis siswa. Hal ini dapat terlihat dari hasil jawaban lembar kerja siswa di kelas dan lembar kerja saat praktikum di laboratorium. Kemapuan siswa untuk menjawab pertanyaan yang disajikan cukup baik. Hal ini didukung oleh hasil penelitian Wijayanti (2013) yang menunjukkan bahwa model pembelajaran Group Investigation (GI) berpengaruh terhadap kemampuan berpikir kritis siswa kelas X SMA Negeri 1 Mejayan Kabupaten Madiun. Proses pembelajaran yang menggunakan model Group Investigation itu menekankan partisipasi dan keaktifan siswa dalam memilih topik materi, melakukan investigasi terhadap suatu masalah, menganalisis hasil yang ditemukan dan mempresentasikan hasilnya (Wijayanti et al., 2013)

Group investigation adalah suatu model pembelajaran yang lebih menekankan pada pilihan dan konrol siswa dari pada menerapkan teknikteknik pengajaran di ruangan kelas. Selain itu juga memadukan prinsip 
Jurnal Binomial Vol. 3 No. 2 September 2020

belajar demokratis di mana siswa terlibat secara aktif dalam kegiatan pembelajaran, baik dari tahap awal sampai akhir pembelajaran termasuk didalamnya siswa mempunyai kebebasan untuk memilih materi yang akan dipelajari sesuai dengan topik yang sedang dibahas, Shoimin (2016).

Penelitian lain yang dilakukan oleh Herlina menyimpulkan bahwa terdapat perbedaan pengaruh terhadap penggunaan model pembelajaran Group Investigation dan model pembelajaran Konvensional terhadap hasil belajar siswa, yang menunjukan bahwa model pembelajaran Group Investigation memiliki pengaruh lebih baik terhadap hasil belajar siswa. Hal ini karena dalam proses pembelajaran Group Investigation pelaksanaannya siswa lebih banyak diberikan kebebasan untuk terlibat langsung dalam proses pembelajaran seperti penetuan topik, menginvestigasi dan memperoleh informasi serta mendiskusikan jawaban dari permasalah yang diterima. Karena adanya keterlibatan seluruh siswa di dalam diskusi kelompok sehingga dapat membuat siswa menjadi lebih aktif. Dengan demikian dapat memberi pengaruh pada kemampuan berpikir kritis siswa. Selain itu, model pembelajaran Group Investigation merupakan model pembelajaran yang dapat melibatkan pengalaman kehidupan seharihari siswa dalam proses pembelajaran (Herlina et al., 2019)

Setelah dilakukan perbaikan di siklus II, siswa sudah aktif dalam berdiskusi dengan anggota kelompoknya dan percaya diri untuk menyajikan hasil diskusi mereka. Hal ini selain karena motivasi yang diberikan, juga karena peneliti mencoba untuk menciptakan suasana belajar yang santai tetapi serius. Sehingga siswa tidak merasa tegang.

Sebagai seorang guru perlu diperhatikan berbagai faktor yang dapat mempengaruhi hasil belajar siswa. Faktor tersebut meliputi faktor eksternal dan internal. Faktor internal yaitu faktor-faktor yang ada dalam diri siswa, meliputi faktor fisiologis, faktor psikologis, faktor kematangan baik fisik maupun psikis.Faktor Eksternal yaitu faktor-faktor yang berada di luar diri siswa meliputi faktor social, faktor budaya Faktor lingkungan fisik, faktor spiritual atau lingkungan keagamaan (Tim Pengembang MKDP,2013) 
Jurnal Binomial Vol. 3 No. 2 September 2020

Pembelajaran dengan menggunakan model pembelajaran Group Investigation merupakan salah satu solusi yang dapat digunakan untuk meningkatkan hasil belajar siswa. Tentunya agar model tersebut dapat berjalan dengan efektif dan efisien, harus didukung oleh lingkungan dan sumber belajar bagi siswa. Seperti kepiawaian guru dalam mengelola kelas, memberikan motivasi dan arahan bagi siswa yang malu dan mungkin belum mengerti serta belum terbiasa dengan langkah-langkah model permbelajaran Group Investigation pada awal pertemuan. Serta yang tidak kalah penting adalah menyediakan lembar kerja siswa yang berisi pertanyaan yang merangsang kemampuan siswa untuk berpikir kritis.

Kedua faktor tersebut tentunya memiliki peranan dalam prestasi siswa. Salah satu faktor intrinsik adalah seperti tingkat prokrastinasi akademik siswa. Prokrastinasi akademik merupakan kebiasaan siswa untuk menunda-nunda yang terkait dengan kegiatan akademik karena sesuatu hal. Hal ini didukung oleh hasil penelitian menunjukkan bahwa semakin tinggi tingkat prokrastinasi akademik siswa maka semakin rendah hasil belajar (Anisa \& Ernawati, 2018)

Selain itu guru juga harus senantiasa menciptakan suasana belajar yang menyenangkan dan meminimalisir gangguan-gangguan yang dapat memecah konsentrasi siswa saat belajar. Seperti penggunaan gadget saat pembelajaran. Penggunaan gadget ibarat pisau bermata dua, jika digunakan untuk mencari referensi materi pelajaran seperti pada saat proses pembelajaran dengan model Group Investigation ini, siswa diperkenankan menggunakan gadget saat belajar. Karena mereka memerlukan sumber informasi lain, selain buku teks yang tersedia. Namun, penggunaan gadget saat proses pembelajaran berlangsung harus tetap diawasi oleh guru. Karena tidak sedikit siswa yang mengambil kesempatan untuk bermain game atau mengakses media social. Tentunya ini berpengaruh kepada konsentrasi belajar siswa dan hasil belajarnya kelak. Hal tersebut didukung oleh hasil penelitian bahwa media sosial berkontribusi negatif terhadap hasil belajar siswa sebesar 12,3\% (A. Anisa, 2020)

Tugas seorang guru untuk mendidik generasi muda penerus bangsa tentu bukanlah hal mudah untuk dilakukan 
Jurnal Binomial Vol. 3 No. 2 September 2020

seperti mebalikkan telapak tangan. Guru harus mempertimbangkan semua faktorfaktor yang dapat mempengaruhi hasil belajar siswanya dan meminimalisir gangguan-gangguan yang dapat memecah konsentrasi siswa saat proses pembelajaran sedang berlangsung.

Sebagai seorang guru tentunya harus selalu memiliki inovasi-inovasi dalam proses pembelajaran dan selalu memperbaiki segala kekurangan yang terjadi selama proses pembelajaran. Salah satunya adalah penggunaan model pembelajaran yang terkini dan bervariasi. Salah satunya adalah Group Investigation yang terbukti dapat meningkatkan hasil belajar siswa.

\section{KESIMPULAN}

Berdasarkan data hasil penelitian yang telah dianalisis bahwa melalui penerapan model pembelajaran Group Investigation dapat meningkatkan hasil belajar siswa kelas XII MIPA 5 pada materi metabolism. Hal ini ditunjukkan dengan adanya peningkatan nilai rata-rata hasil belajar pada siklus I adalah 62,06 dan pada siklus II adalah 86,94.

\section{UCAPAN TERIMA KASIH}

Ucapan terima kasih peneliti ucapkan kepada semua pihak yang telah memberikan bantuannya dalam penelitian ini khususnya kepada rekanrekan guru di SMA Negeri 1 Makassar.

\section{DAFTAR PUSTAKA}

A. Anisa, E. E. (2020). Pengaruh Media Sosial Terhadap Hasil Belajar Biologi Siswa SMA Negeri Di Kota Makassar. Jurnal Binomial, 3(1), 39-48. https://ejournals.umma.ac.id/index. php/binomial/article/view/479

Anisa, A., \& Ernawati, E. (2018). Pengaruh prokrastinasi akademik terhadap hasil belajar biologi siswa SMA Negeri di Kota Makassar. Jurnal Biotek. https://doi.org/10.24252/jb.v6i2. Herlina, M., Rahayu, I. Y., \& Wiksya, D. (2019). Pengaruh Model Pembelajaran Group Investigation (GI) Terhadap Berpikir Kritis Dan Keterampilan Sosial Siswa Dalam Pembelajaran Ipa Biologi Kelas X Sman 2 Argamakmur. Diklabio: Jurnal Pendidikan Dan Pembelajaran Biologi. https://doi.org/10.33369/diklabio.3. 2.142-152

Suryanda, A., Azrai, E. P., \& Wari, N. (2018). Pengaruh penerapan model pembelajaran Group Investigation (GI) terhadap kemampuan berpikir analisis siswa pada materi pencemaran lingkungan. Biosfer: Jurnal Pendidikan Biologi. https://doi.org/10.21009/biosferjpb .9-2.6 
Wijayanti, W., Herlambang, S., \& K, M. S. (2013). Pengaruh Model Pembelajaran Group Investigation (Gi) Terhadap Kemampuan Berpikir Kritis Siswa Kelas X Sma Negeri 1 Mejayan Kabupaten Madiun. Jurnal Pendidikan Geografi Universitas Negeri Malang.

Darmadi,H. 2017. Pengembangan Model dan Metode Dalam Dinamika Belajar Siswa. Yogyakarta: Deepublish.

Shoimin aris. 2016. 68 model pembeljaran inovatif dalam kurikulum 2013. Yogyakarta: ar -ruzzmedia kencana prenada media group: jakarta.

Tim Pengembang MKDP. 2013. Kurikulum \& Pembelajaran. Jakarta: PT Rajagrafindo Persada. 